\title{
IDENTIFIKASI DAN ANTAGONISME JAMUR ENDOFIT TANAMAN TEBU (Saccharum officinarum L.) DALAM MENGHAMBAT Xanthomonas albilineans L. PENYEBAB PENYAKIT VASKULAR BAKTERI
}

\author{
Siti Hardianti Wahyuni*, Hasanuddin dan Edison Purba \\ Program Studi Magister Agroekoteknologi. Fakultas Pertanian USU. Medan 20155 \\ *Corresponding author: sitihardiantiw@yahoo.com
}

\begin{abstract}
Identification and antagonism test endophytic fungi of sugarcane (Saccharum officinarum L.) to control bacterial vascular (Xanthomonas albilineans). This research aims to find potential endophytic fungi to against $X$. albilineans on sugarcane with use method autoclaving and membrane filtration sterilization. The research was conducted at Plant Disease Laboratory, Agroecotechnology Program Study, Faculty of Agriculture, University of Sumatera Utara, Medan from April to December 2014. It was done by using Completely Randomized Design (CRD) Factorial with three factor and three replications. The first factor were endophytic fungi 1, endophytic fungi 2. The second factor were dilution $10^{-1}, 10^{-2}, 10^{-3}$ dan $10^{-4}$. The three factor sterilization method were autoclaving and membrane filtration. The results showed all the endophytic fungi Aspergillus sp. better use membrane filtration sterilization and Hormiscium sp. better use autoclaving sterilization. Both fungi are potentially as biological agents to control bacterial vascular wilt on sugarcane. The best results obtained on Hormiscium sp.with diameter of inhibiting zone 9,04 $\mathrm{mm}$ with use autoclaving sterilization.
\end{abstract}

Keywords : Sugarcane, Saccharum officinarum, endophytic, fungi, sterilization.

\section{ABSTRAK}

Identifikasi dan uji antagonisme jamur endofit tebu (Saccharum officinarum L.) dalam menghambat Xanthomonas albilineans penyebab penyakit vaskular bakteri. Penelitian ini bertujuan untuk menguji potensi jamur endofit terhadap $X$. albilineans penyebab penyakit vaskular bakteri pada tanaman tebu dengan menggunakan dua metode sterilisasi autoklaf dan membran filter. Penelitian ini dilaksanakan di Laboratorium Penyakit Tumbuhan, Program Studi Agroekoteknologi, Fakultas Pertanian Universitas Sumatera Utara, Medan mulai bulan April sampai Desember 2014. Penelitian ini menggunakan Rancangan Acak Lengkap (RAL) Faktorial dengan tiga faktor dan tiga ulangan. Faktor pertama jamur endofit (J) yaitu jamur endofit 1, jamur endofit 2. Faktor kedua pengenceran (P) yaitu $10^{-1}, 10^{-2}, 10^{-3}$ dan $10^{-4}$. Faktor ketiga metode sterilisasi yaitu autoklaf (A) dan membran filter (M). Hasil penelitian menunjukkan jenis jamur endofit Aspergillus sp. lebih baik menggunakan sterilisasi membran filter dan Hormiscium sp. lebih baik menggunakan sterilisasi autoklaf. Kedua jamur tersebut berpotensi sebagai agens hayati untuk mengendalikan penyakit vaskular bakteri pada tebu. Hasil terbaik didapat pada Hormiscium sp. dengan diameter zona hambat 9,04 mm menggunakan sterilisasi autoklaf.

Kata kunci : Tebu, Saccharum officinarum, endofit, jamur, sterilisasi.

\section{PENDAHULUAN}

Tebu merupakan bahan baku utama pembuatan gula di Indonesia. Luas areal pertanaman tebu di Indonesia saat ini sesungguhnya hanya berkisar antara $340-$ 350 ribu ha/tahun. Sekitar $70 \%$ dari areal pertanaman itu merupakan tebu rakyat 
(Malian et al., 2004). Kebutuhan gula nasional meningkat setiap tahun akibat pertambahan penduduk, perbaikan pendapatan masyrakat, serta perkembangan industri makanan dan minuman. Laju peningkatan konsumsi gula diperkirakan sekitar $3.3 \%$ per tahun (Mardianto et al., 2005). Penurunan produksi gula nasional beberapa tahun terakhir ini disebabkan oleh beberapa hal. Salah satunya karena penyakit. Rata - rata penurunan produksi gula karena serangan penyakit diperkirakan sekitar $10 \%$ (BPPT, 2007). Di antara penyakit tanaman tersebut, penyakit yang disebabkan oleh bakteri Xanthomonas albilineans L. merupakan penyakit yang sering dijumpai di pertanaman tebu.

Gejala serangan timbulnya klorosis pada daun yang mengikuti alur pembuluh. Jalur klorosis ini lama-lama menjadi kering. Penyakit blendok terlihat kira-kira 6 minggu hingga 2 bulan setelah tanam. Jika daun terserang berat, seluruh daun bergaris-garis hijau dan putih (Pusat Penelitian dan Pengembangan Perkebunan, 2010).

Bakteri ini dapat hidup sebagai saprofit dalam tanah dan menular melalui perantaraan alat yang digunakan untuk memotong stek tebu yang tidak steril serta dengan tertiup angin dan hujan sehingga harus dilakukan pergiliran tanaman agar mengurangi timbulnya penyakit (Birch, 2001). Penerapan teknik-teknik pengendalian lainnya seperti menanam varietas tahan, solarisasi tanah (Widodo dan Suheri, 1995) dan penggunaan agen hayati diantaranya mikroorganisme antagonis seperti jamur dan bakteri endofit (Azevedo et al., 2000; Strobel et al., 2004).

Endofit umumnya berasal dari golongan jamur ataupun bakteri (Strobel et al., 2004). Jamur endofit merupakan salah satu sumber utama mikrobia penghasil antibiotik (Kauffman dan Carver, 1997; Kurtz, 1997). Jamur ini menginfeksi tanaman sehat pada jaringan tertentu dan mampu menghasilkan mikotoksin, enzim serta antibiotika (Sinaga, 2009). Brunner dan Petrini (1992) melakukan skrining terhadap lebih dari 80 spora jamur, didapatkan bahwa
79\% jamur yang mampu menghasilkan antibiotik adalah kelompok endofit. Melalui kemajuan bioteknologi, saat ini endofit dimanfaatkan sebagai sarana produksi antibiotik untuk keperluan obat dan farmasi, pertanian, serta sarana transgenik gen-gen ketahanan (Yulianti, 2012).

Berdasarkan latar belakang yang telah dipaparkan, dapat diketahui bahwa dalam tanaman terdapat jamur endofit yang memiliki manfaat yang sangat penting bagi tumbuhan. Simbiosis antara jamur endofit dengan tanaman tebu dapat digunakan sebagai antibakteri.

\section{BAHAN DAN METODE}

Penelitian ini dilaksanakan di Laboratorium Penyakit Tumbuhan Fakultas Pertanian Universitas Sumatera Utara, Medan dengan ketinggian tempat $\pm 25 \mathrm{~m} \mathrm{dpl}$ mulai bulan April hingga Desember 2014.

Penelitian ini menggunakan rancangan acak lengkap 3 faktor antara lain: faktor 1 : Jamur endofit terdiri dari J1 : Jamur Endofit 1, J2 : Jamue Endofit 2, dan faktor 2 : pengenceran $10^{-1}, 10^{-2}, 10^{-3}$ dan $10^{-4}$, faktor 3 : metode sterilisasi : autoklaf dan membran filter, menggunakan tiga ulangan.

\section{Pelaksanaan Penelitian \\ Isolasi bakteri $X$. albilineans}

Bagian tanaman tebu yang terserang penyakit vaskular bakteri $X$. albilineans dibersihkan dengan air mengalir, lalu dipotong dengan ukuran 2-3 cm. Setelah itu sampel direndam dengan etanol $70 \%$ selama 30 detik, kemudian direndam dengan $0.1 \%$ $\mathrm{HgCl}$ selama 3 menit dan dibilas dengan air suling steril 2-3 kali. Selanjutnya sampel digerus dengan mortal steril dan diberikan sedikit air (1ml), lalu tambahkan $9 \mathrm{ml}$ air suling steril untuk pengenceran. Pengenceran dilakukan $10^{-3}-10^{-5}$, kemudian dihomogenkan selama 2 menit. Selanjutnya disebar $0,1 \mathrm{ml}$ di atas media YDCA, diinkubasi pada suhu ruang selama 24 jam. 


\section{Pewarnaan Gram Bakteri}

Bakteri yang berhasil diisolasi dan telah murni dibiakan dalam media NA. Setelah diinkubasi selama \pm 48 jam kemudian diamati morfologi koloni bakteri tersebut. Biakan murni bakteri yang telah ditanam pada cawan petri diidentifikasi morfologi sel nya dengan pewarnaan gram. Bila bakteri tetap berwarna ungu diakhir pewarnaan, berarti bakteri bersifat Gram-positif, tetapi bila setelah di beri larutan pemucat (alkohol/etanol) berubah warna menjadi merah maka bakteri bersifat Gram-negatif.

\section{Eksplorasi Jamur Endofit dari Tanaman Tebu}

Tebu varietas BZ 134 yang akan dijadikan sampel diambil dari beberapa lokasi di PTPN II Sei Semayang. Jamur endofit diperoleh dengan mengisolasi akar, batang, dan daun tanaman tebu yang sehat. Sterilisasi bagian tanaman dilakukan secara bertahap dengan merendam selama 60 detik dalam alkohol 70\%, $\mathrm{NaOCl} 3 \%$ selama 60 detik, dan etanol $70 \%$ selama 30 detik. Kemudian dibilas sebanyak dua kali dengan aquades steril dan dikeringkan di atas kertas saring steril. Bagian tanaman dibelah untuk ditumbuhkan dalam media PDA. Jamur yang tumbuh dari dalam jaringan tanaman dimurnikan dalam media PDA (Rodriques, 1994).

\section{Identifikasi isolat jamur endofit}

Semua jamur endofit yang didapat selanjutnya diidentifikasi dengan melihat ciri makroskopis dan mikroskopis, dengan mengacu pada buku petunjuk klasifikasi Illustrated Genera Imperfect Fungi menurut Barnett dan Hunter (1972) dan Illustrated Manual on Identification of Seed-borne Fungi menurut Hyun et al (2004).

\section{Seleksi Jamur Endofit Penghasil Crude Antibiotik}

Produksi metabolit antimikroba oleh jamur endofit dilakukan dengan cara menumbuhkannya di dalam medium PDB. Koloni jamur endofit yang telah diinkubasi pada medium PDA selama 48 jam pada suhu $25^{\circ} \mathrm{C}$, diambil 5 cork bore dengan menggunakan jarum ose dan diinokulasikan ke medium PDB dalam Erlenmeyer $100 \mathrm{ml}$. Kemudian diinkubasi pada suhu $25^{\circ} \mathrm{C}$ dalam shaker incubator $130 \mathrm{rpm}$ (Sunarmi, 2010) selama 5-7 hari lalu disaring dengan kertas saring Wattman 041 untuk mendapatkan suspensi antibiotik. Suspensi antibiotik disentrifugasi dengan kecepatan 3800 rpm selama 20 menit. Supernatan dibagi menjadi dua bagian (A dan B) dan diambil untuk sterilisasi dengan cara yaitu sterilisasi autoklaf dan membran filter (Pavithra et al., 2012) :

\section{a. Sterilisasi Autoklaf}

Supernatan A dimasukkan ke erlenmeyer kemudian ditutup dengan kapas steril dan aluminium foil, disterilkan dalam autoklaf dengan suhu $121^{\circ} \mathrm{C}$ selama 15 menit. Hasil tersebut adalah suspensi antibiotik yang digunakan dapat melakukan ekstraksi crude antibiotik.

b. Sterilisasi Membran Filter

Supernatan B disterilisasi dengan membran filter ukuran pori $0,45 \mu \mathrm{m}$ dan $0,22 \mu \mathrm{m}$ sehingga mikroba tertahan dalam pada filter tersebut. Filter ini sebelumnya telah disterilkan dengan autoklaf.. Hasil tersebut adalah suspensi antibiotik yang telah steril digunakan agar dapat melakukan ekstraksi crude antibiotik (Abimbola, 2014).

\section{Ekstraksi Crude Antibiotik}

Suspensi antibiotik diekstraksi dengan pelarut Chloroform dengan perbandingan 1:1 (v/v). Campuran pelarut dan suspensi antibiotik dihomogenkan sebelum dimasukkan ke dalam corong pemisah, kemudian didinginkan kedalam lemari pendingin selama 4 jam pada suhu $9-10^{\circ} \mathrm{C}$ untuk optimalisasi pengikatan pelarut terhadap antibiotik (Tawiah et al., 2012). Campuran pelarut dan suspensi antibiotik ditampung dalam beaker glass (yang telah ditimbang beratnya) dan diuapkan sampai kering di dasar beaker glass, endapan ini adalah crude antibiotik yang perlu diketahui beratnya dengan cara menimbang kembali berat kotor beaker glass untuk menekan berat antibiotik yang diperoleh. Endapan crude 
Vol.3, No.1. April 2016. (4) : 31- 42

antibiotik yang didapatkan diencerkan dengan alkohol $96 \%$ dan simpan botol universal sebagai cairan stok (Abimbola, 2014).

Berat crude antibiotik = berat kotor beaker glass - berat bersih beaker glass.

\section{Pengujian antagonis crude antibiotik} jamur endofit dengan bakteri patogen

Pengujian dilakukan antara $X$. albilnieans dengan antibiotik jamur endofit yang didapat dalam satu cawan petri yang berdiameter $9 \mathrm{~cm}$. Uji antagonisme dilakukan dengan cara memasukkan koloni dari biakan murni $X$. albilnieans ke dalam media NA kemudian dituang pada satu cawan petri. Uji aktivitas antibakteri isolat jamur terhadap bakteri patogen dilakukan dengan metode uji Kirby-Bauer menggunakan kertas cakram. Kertas cakram dibuat dari kertas saring Whatman dengan cara mengguntingnya dengan alat pembolong kertas sehingga didapatkan kertas cakram dengan diameter 6 mm (Cappucino dan Sherman, 1996).

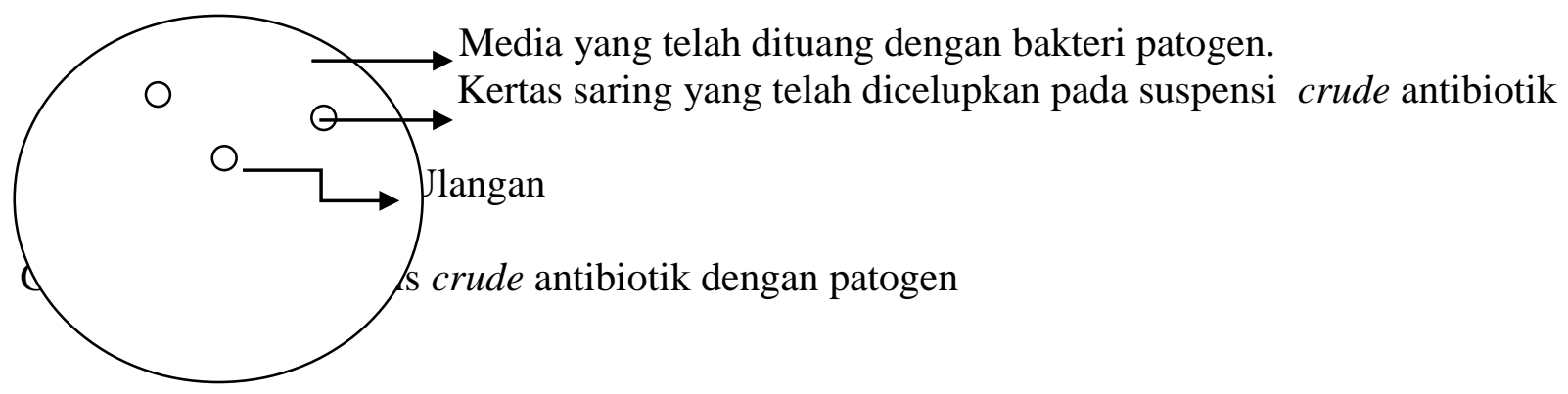

Secara aseptik, kertas cakram yang sudah disterilkan direndam di dalam supernatan kultur jamur endofit selama 30 menit. Kertas cakram diambil dengan menggunakan pinset steril dan diletakkan di atas medium uji aktivitas antimikroba (medium plat NA). Kemudian diinkubasi selama $18-24$ jam pada suhu $37^{\circ} \mathrm{C}$. Setelah Peubah amatan

\section{Identifikasi isolat jamur endofit}

Semua jamur endofit yang didapat diidentifikasi dengan melihat ciri makroskopis dan mikroskopis dengan mengacu pada buku petunjuk klasifikasi Illustrated Genera Imperfect Fungi menurut Barnett dan Hunter (1972) dan Illustrated Manual on Identification of Seed-borne Fungi menurut Hyun et al (2004).

\section{Zona hambat (mm)}

Pengamatan dilakukan dengan mengukur zona bening yang dihasilkan jamur endofit terhadap $X$. albilnieans. Setelah masa inkubasi diameter zona bening di sekitar cakram diukur dengan menggunakan kertas millimeter. Aktifitas ekstrak dapat dilihat dengan adanya zona bening di sekitar cakram. Zona hambat masa inkubasi selesai, dilakukan pengamatan terhadap zona jernih yang terbentuk dan diukur diameternya. Sampel yang mempunyai potensi menghasilkan zat antimikroba ditunjukkan dengan adanya zona jernih. Pertumbuhan jamur diamati setiap hari mulai 1 hari setelah inokulasi (HSI).

yang terbentuk di sekitar cakram diukur diameter vertikal dan diameter horizontal dengan satuan milimeter (mm). Diameter zona hambat dihitung dengan rumus sebagai berikut:

$$
\text { Zona hambat }=\mathrm{A}-\mathrm{B}
$$

Keterangan :

$\mathrm{A}=$ Diameter zona bening yang terbentuk $(\mathrm{mm})$

$\mathrm{B}=$ Diameter kertas cakram $(\mathrm{mm})$

(Rante et. al, 2013).

\section{HASIL DAN PEMBAHASAN}

\section{Identifikasi Isolat Jamur Endofit dari Tanaman Tebu}

Berdasarkan hasil pengamatan yang telah dilakukan, jamur endofit yang berhasil diisolasi dari tanaman tebu didapatkan isolat jamur, identifikasi dilakukan dengan petunjuk klasifikasi menurut Barnet dan Hunter (1972). 
Hasil identifikasi isolat jamur endofit dari tanaman tebu yang sehat. Isolat jamur tersebut diidentifikasi sebagai berikut:

\section{Aspergillus sp.}

Koloni berwarna hitam, koloni tebal dan diisolasi dari akar tanaman tebu dan ditumbuhkan pada medium PDA. Memiliki hifa aseptat, konidiofor panjang dan membengkak menjadi vesikel pada ujungnya membawa sterigma dimana tumbuh konidia. Memiliki konidia 1 sel, berbentuk bulat dan hyalin. Menurut Barnett dan Hunter (1998) jamur Aspergillus yang diisolasi, secara visual koloninya tampak memiliki lapisan basal berwarna putih hingga kuning dengan lapisan konidiofor yang lebat berwarna coklat tua hingga hitam. Tangkai konidiofor (stipe) tidak berornamentasi/berdinding halus dan berwarna transparan (hialin). Kepala konidia berwarna hitam dan berbentuk bulat. Konidia berbentuk bulat hingga semi bulat, berwarna coklat tua. Konidia terbentuk dari fialid yang menumpang pada metula (tipe biseriate) dan membentuk formasi sikat melingkar (radiate collumnar).

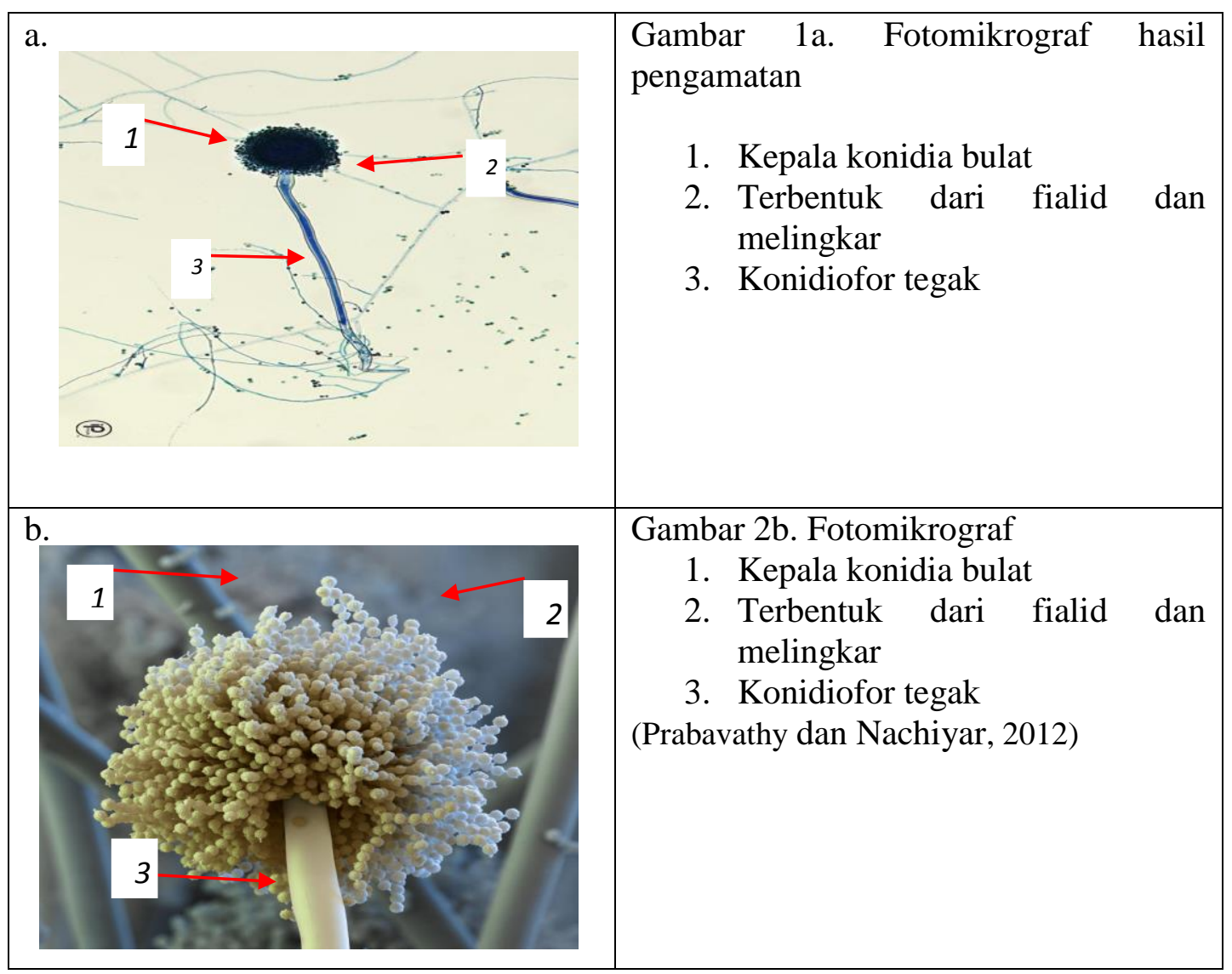

Gambar 1. Aspergillus sp.

Aspergillus sp. mampu menghasilkan metabolit sekunder yang aktif. Singh dan Bharate (2005) bahwa secara umum senyawa antimikroba yang dihasilkan oleh Aspergillus bersifat netral, polar, dan memiliki gugus fenol. Fenol ini mampu mendenaturasikan

2. Hormiscium sp.

Koloni jamur endofit berwarna putih kasar yang merupakan kumpulan hifa. Tepi koloni tidak rata dan berwarna putih berserabut pada medium PDA. Dilihat dari protein pada dinding dan membran sel bakteri dan fungi. Menurut Maria et al. (2005) cendawan endofit dari genus Aspergillus dapat menghasilkan senyawa antibiotik yang bersifat antagonis dan dapat berperan dalam ketahanan tanaman.

bawah tampak berwarna kuning. Jamur endofit diisolasi dari batang tanaman tebu yang ditumbuhkan pada medium PDA. Jamur endofit ini memiliki konidiofor pendek seperti 


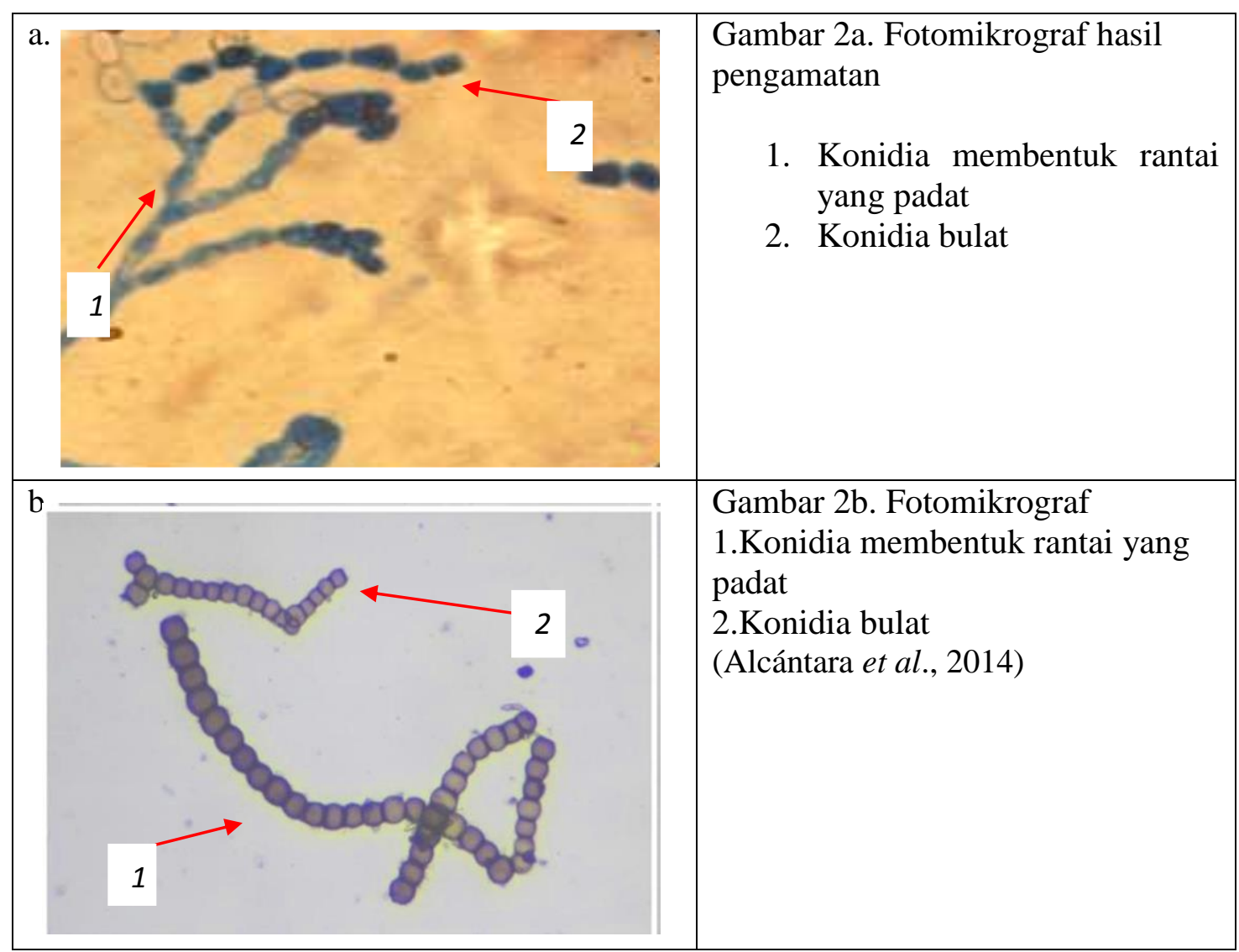

Gambar 2. Hormiscium sp.

\section{Zona Hambat}

\section{Diameter zona hambat 1 HSI}

Data pengamatan diameter zona hambat pengamatan 1 hari setelah inokulasi (HSI). Hasil analisis menunjukkan bahwa perlakuan jenis jamur endofit dan pengenceran berpengaruh nyata terhadap parameter zona hambat pada pengamatan 1 HSI sedangkan perlakuan sterilisasi tidak berbeda nyata terhadap parameter zona hambat pada pengamatan 1 HSI. Perlakuan interaksi antara jenis jamur endofit dengan sterilisasi menunjukkan pengaruh yang nyata dan interaksi jamur dengan pengenceran, interaksi antara sterilisasi dengan pengenceran dan interaksi antara jenis jamur endofit, sterilisasi dan pengenceran menunjukkan pengaruh yang tidak nyata terhadap parameter zona hambat pada pengamatan 1 HSI terhadap diameter zona hambat pada pengamatan 1 HSI. Rataan diameter zoa hambat pengamatan 1 HSI dapat dilihat pada Tabel 1.

Tabel 1. Diameter zona hambat (mm) pada 1 HSI

\begin{tabular}{lrrr}
\hline \multirow{2}{*}{ Perlakuan } & \multicolumn{3}{c}{ Jamur } \\
\cline { 2 - 4 } & $\mathrm{J} 1$ & $\mathrm{~J} 2$ & Rataan \\
\hline Sterilisasi & & & \\
A & $0.33 \mathrm{~b}$ & $8.20 \mathrm{a}$ & 4.27 \\
M & $4.33 \mathrm{a}$ & $3.22 \mathrm{~b}$ & 3.78 \\
\hline
\end{tabular}




\begin{tabular}{lccc}
$\begin{array}{l}\text { Jurnal Pertanian Tropik } \\
\text { Vol.3, No.1. April 2016. (4) : 31-42 }\end{array}$ & & \\
\hline Pengenceran & 3.33 & 8.93 & $6.13 \mathrm{a}$ \\
P1 & 2.67 & 6.08 & $4.38 \mathrm{~b}$ \\
P2 & 2.67 & 4.38 & $3.53 \mathrm{c}$ \\
\hline P3 & 0.67 & 3.43 & $2.05 \mathrm{~d}$ \\
P4 & & & \\
\hline Interaksi & 0.67 & 12.87 & 6.77 \\
AP1 & 0.33 & 8.33 & 4.33 \\
AP2 & 0.33 & 6.27 & 3.30 \\
AP3 & 0.00 & 5.33 & 2.67 \\
AP4 & 6.00 & 5.00 & 5.50 \\
MP1 & 5.00 & 3.83 & 4.42 \\
MP2 & 5.00 & 2.50 & 3.75 \\
MP3 & 1.33 & 1.53 & 1.43 \\
MP4 & $2.33 \mathrm{~b}$ & $5.71 \mathrm{a}$ & 4.02 \\
\hline Rataan
\end{tabular}

Keterangan : - Angka-angka yang diikuti oleh huruf yang sama pada baris dan kolom yang sama pada kelompok perlakuan yang sama tidak berbeda nyata menurut uji jarak berganda duncan/DMRT pada $\alpha=5 \%$.

- J1 : Aspergillus sp., J2 : (Hormiscium sp.), P1 : Pengenceran 1 x $10^{-1}$, P2 : Pengenceran $1 \times 10^{-2}, \mathrm{P} 3$ : Pengenceran $1 \times 10^{-3}, \mathrm{P} 4: 1 \times 10^{-4}, \mathrm{~A}:$ Metode sterilisasi autoklaf, M : Metode sterilisasi membran filter, HSI : Hari Setelah Inokulasi.

Tabel 1 menunjukkan bahwa pada perlakuan jamur endofit, diameter zona hambat tertinggi terdapat pada jamur endofit 2 (Hormiscium sp.) $(5.71 \mathrm{~mm})$ yang berbeda nyata dengan perlakuan jamur endofit 1 (Aspergillus sp.) $(2,33 \mathrm{~mm})$. Pada perlakuan metode sterilisasi, secara umum metode sterilisasi dengan membran filter dapat meningkatkan zona hambat jika dbandingkan dengan metode autoklaf. Sedangkan secara

Data pengamatan diameter zona hambat pengamatan 2 hari setelah inokulasi (HSI). Hasil analisis menunjukkan bahwa perlakuan jenis jamur endofit, sterilisasi, dan pengenceran berpengaruh nyata terhadap parameter zona hambat pada pengamatan 2 HSI. Perlakuan interaksi antara jenis jamur endofit dengan sterilisasi menunjukkan pengaruh yang nyata dan interaksi jamur dengan pengenceran, interaksi antara sterilisasi dengan pengenceran dan interaksi antara jenis jamur endofit, sterilisasi dan pengenceran menunjukkan pengaruh yang tidak nyata terhadap parameter zona hambat pada pengamatan 2 HSI terhadap diameter zona hambat pada pengamatan 2 HSI. Rataan diameter zoa hambat pengamatan 2 HSI dapat dilihat pada Tabel 2 . spesifik, tidak terdapat perbedaan metode sterilisasi antara autoklaf dengan membran filter pada jenis jamur endofit 1 (Aspergillus sp.) dan jamur endofit 2 (Hormiscium sp.). Zona hambat tertinggi pada perlakuan sterilisasi autoklaf terdapat pada Pada jamur endofit 2 (Hormiscium sp.) yaitu 8,20 mm.

\section{Diameter zona hambat 2 HSI}

Tabel 2 menunjukkan bahwa pada perlakuan jamur endofit, diameter zona hambat tertinggi terdapat pada jamur endofit 2 (Hormiscium sp.) $(6,09 \mathrm{~mm})$ yang tidak berbeda nyata dengan perlakuan jamur endofit 1 (Aspergillus sp.) $(3,58 \mathrm{~mm})$. Pada perlakuan metode sterilisasi, secara umum metode sterilisasi dengan membran filter dapat meningkatkan zona hambat jika dbandingkan dengan metode autoklaf. Sedangkan secara spesifik, tidak terdapat perbedaan metode sterilisasi antara autoklaf dengan membran filter pada jenis jamur endofit 1 (Aspergillus sp.) dan jamur endofit 2 (Hormiscium sp.). Zona hambat tertinggi pada perlakuan sterilisasi autoklaf terdapat pada jamur endofit 2 (Hormiscium sp.) yaitu 8,68 $\mathrm{mm}$. 
Tabel 2. Diameter zona hambat (mm) pada 2 HIS

\begin{tabular}{lrrr}
\hline \multirow{2}{*}{ Perlakuan } & \multicolumn{3}{c}{ Jamur } \\
\cline { 2 - 4 } & $\mathrm{J} 1$ & $\mathrm{~J} 2$ & Rataan \\
\hline Sterilisasi & & & \\
A & $0.58 \mathrm{~b}$ & $8.68 \mathrm{a}$ & $4.63 \mathrm{~b}$ \\
M & $6.58 \mathrm{a}$ & $3.51 \mathrm{~b}$ & $5.05 \mathrm{a}$ \\
\hline Pengenceran & & & \\
P1 & 4.17 & 9.38 & $6.78 \mathrm{a}$ \\
P2 & 4.33 & 6.43 & $5.38 \mathrm{ab}$ \\
P3 & 3.67 & 4.72 & $4.19 \mathrm{~b}$ \\
P4 & 2.17 & 3.83 & $3.00 \mathrm{c}$ \\
\hline Interaksi & & & \\
AP1 & 1.00 & 13.47 & 7.23 \\
AP2 & 0.67 & 8.73 & 4.70 \\
AP3 & 0.67 & 6.73 & 3.70 \\
AP4 & 0.00 & 5.77 & 2.88 \\
MP1 & 7.33 & 5.30 & 6.32 \\
MP2 & 8.00 & 4.13 & 6.07 \\
MP3 & 6.67 & 2.70 & 4.68 \\
MP4 & 4.33 & 1.90 & 3.12 \\
\hline Rataan & $3.58 \mathrm{~b}$ & $6.09 \mathrm{a}$ & 4.84 \\
\hline Kany
\end{tabular}

Keterangan : - Angka-angka yang diikuti oleh huruf yang sama pada baris dan kolom yang sama pada kelompok perlakuan yang sama tidak berbeda nyata menurut uji jarak berganda duncan/DMRT pada $\alpha=5 \%$.

- J1 : Aspergillus sp., J2 : (Curvularia sp.), P1 : Pengenceran $1 \times 10^{-1}$, P2 : Pengenceran $1 \times 10^{-2}$, P3 : Pengenceran $1 \times 10^{-3}, \mathrm{P} 4: 1 \times 10^{-4}, \mathrm{~A}:$ Metode sterilisasi autoklaf, M : Metode sterilisasi membran filter, HSI : Hari Setelah Inokulasi.

\section{Diameter zona hambat 3 HSI}

Data pengamatan diameter zona hambat pengamatan 3 hari setelah inokulasi (HSI). Hasil analisis menunjukkan bahwa perlakuan jenis jamur endofit, pengenceran dan sterilisasi berpengaruh nyata terhadap parameter zona hambat pada pengamatan 3 HSI.

Perlakuan interaksi antara jenis jamur endofit dengan sterilisasi menunjukkan pengaruh yang nyata dan interaksi jamur dengan pengenceran, interaksi antara sterilisasi dengan pengenceran dan interaksi antara jenis jamur endofit, sterilisasi dan pengenceran menunjukkan pengaruh yang tidak nyata terhadap parameter zona hambat pada pengamatan 3 HSI terhadap diameter zona hambat pada pengamatan 3 HSI. Rataan diameter zoa hambat pengamatan 3 HSI dapat dilihat pada Tabel 3 .
Tabel 3 menunjukkan bahwa pada perlakuan jamur endofit, diameter zona hambat tertinggi terdapat pada jamur endofit 2 (Hormiscium sp.) $(6,52 \mathrm{~mm})$ yang berbeda nyata dengan perlakuan jamur endofit 1 (Aspergillus sp.) $(4,40 \mathrm{~mm})$. Pada perlakuan metode sterilisasi, secara umum metode sterilisasi dengan membran filter dapat meningkatkan zona hambat jika dbandingkan dengan metode autoklaf. Sedangkan secara spesifik, tidak terdapat perbedaan metode sterilisasi antara autoklaf dengan membran filter pada jenis jamur endofit 1 (Aspergillus sp.) dan jamur endofit 2 (Hormiscium sp.). Zona hambat tertinggi pada perlakuan sterilisasi autoklaf terdapat pada Pada jamur endofit 2 (Hormiscium sp.) yaitu 9,04 mm. 
Tabel 3. Diameter zona hambat (mm) pada 3 HIS

\begin{tabular}{lrrr}
\hline \multirow{2}{*}{ Perlakuan } & \multicolumn{3}{c}{ Jamur } \\
\cline { 2 - 4 } & $\mathrm{J} 1$ & $\mathrm{~J} 2$ & Rataan \\
\hline Sterilisasi & & & \\
A & $0.67 \mathrm{~b}$ & $9.04 \mathrm{a}$ & $4.85 \mathrm{~b}$ \\
M & $8.13 \mathrm{a}$ & $3.99 \mathrm{~b}$ & $6.06 \mathrm{a}$ \\
\hline Pengenceran & & & \\
P1 & 5.50 & 9.80 & $7.65 \mathrm{a}$ \\
P2 & 5.42 & 6.80 & $6.11 \mathrm{~b}$ \\
P3 & 4.33 & 5.23 & $4.78 \mathrm{c}$ \\
P4 & 2.33 & 4.23 & $3.28 \mathrm{~d}$ \\
\hline Interaksi & & & \\
AP1 & 1.00 & 13.87 & 7.43 \\
AP2 & 1.00 & 9.03 & 5.02 \\
AP3 & 0.67 & 7.13 & 3.90 \\
AP4 & 0.00 & 6.13 & 3.07 \\
MP1 & 10.00 & 5.73 & 7.87 \\
MP2 & 9.83 & 4.57 & 7.20 \\
MP3 & 8.00 & 3.33 & 5.67 \\
MP4 & 4.67 & 2.33 & 3.50 \\
\hline Rataan & $4.40 \mathrm{~b}$ & $6.52 \mathrm{a}$ & 5.46 \\
\hline
\end{tabular}

Keterangan : - Angka-angka yang diikuti oleh huruf yang sama pada baris dan kolom yang sama pada kelompok perlakuan yang sama tidak berbeda nyata menurut uji jarak berganda duncan/DMRT pada $\alpha=5 \%$.

- J1 : Aspergillus sp., J2 : (Curvularia sp.), P1 : Pengenceran $1 \times 10^{-1}, \mathrm{P} 2$ : Pengenceran $1 \times 10^{-2}, \mathrm{P} 3$ : Pengenceran $1 \times 10^{-3}, \mathrm{P} 4: 1 \times 10^{-4}, \mathrm{~A}$ : Metode sterilisasi autoklaf, M : Metode sterilisasi membran filter, HSI : Hari Setelah Inokulasi.

Hal ini menunjukkan bahwa isolat jamur endofit 2 (Hormiscium sp.) tahan terhadap sterilisasi autoklaf. Besarnya zona hambat tersebut menunjukkan adanya potensi dari isolat untuk diteliti dan dikembangkan lebih lanjut untuk diisolasi senyawa metabolit sekunder berupa antimikroba atau mungkin antibiotik yang dihasilkan sehingga diharapkan dapat memberikan solusi untuk masalah resistensi. Adanya variasi besar zona hambat yang diperoleh mungkin disebabkan oleh perbedaan sifat yang dimiliki bakteri uji yang digunakan baik secara morfologi dan fisiologi. Selain itu, juga disebabkan oleh senyawa metabolit sekunder yang dihasilkan oleh masing-masing isolat memiliki struktur kimia, komposisi dan kandungan / konsentrasi yang berbeda dengan antibiotik kontrol (Dharmawan et al. 2009).

Tabel 1, 2 dan 3 menunjukkan isolat jamur 1 (Aspergillus sp.) tidak tahan terhadap sterilisasi autoklaf dan lebih baik disterilisasi dengan membran filter, hal tersebut terlihat dari besar kecilnya zona hambat jamur tersebut. Menurut Cappucino dan Sherman (1996), faktor-faktor yang mempengaruhi timbulnya zona hambat berupa kemampuan difusi bahan antimikroba ke dalam media dan interaksinya dengan mikroba yang diuji, jumlah mikroba yang diujikan, kecepatan tumbuh mikroba uji, dan tingkat sensitifitas mikroba terhadap bahan antimikroba. Ada beberapa dugaan lain mengapa suatu isolat jamur tidak menunjukkan kepekaan senyawa antimikroba, pertama, isolat jamur tersebut memiliki gen untuk mengkode terbentuknya senyawa metabolit namun tidak terekspresi pada keadaan normal sehingga perlu diinduksi oleh senyawa tertentu (Demain, 1998), kedua, isolat tersebut menghasilkan senyawa antimikroba namun tidak bersifat aktif terhadap bakteri uji, dan yang ketiga, jamur tersebut menghasilkan senyawa antimikroba intraseluler sehingga senyawa 


\section{SIMPULAN}

Jamur endofit Aspergillus sp. dan Hormiscium sp. mempunyai kemampuan menghambat $X$. albilineans. Aspergillus sp. lebih baik diterilisasi dengan menggunakan membran filter dan Hormiscium sp. baik disterilisasi dengan autoklaf. Diameter zona hambat tertinggi terdapat pada sterilisasi dengan autoklaf yaitu 9,04 $\mathrm{mm}$.

\section{DAFTAR PUSTAKA}

Abimbola, I.O. 2014. The effect of autoclaving and membrane filtration on the antimicrobial activities of Alchornea cordifolia leaf extract. $J$. Microbiol. 4(1):6-9.

Alcántara, D.M., Muñoz, M.R., Canales, M.P., Aristimuño, D.E., Castillo, J.G.L. 2014. Estudio de la Micobiota del Norte de Marruecos i. Micología. Botánica. 1-3.

Azevedo, J.L.W., Maccheroni J.R., Pereira, J.O. and Luiz, A.W. 2000. Endophytic microorganism: A review on insect control and recent advances on tropical plants. Biotech. 3(1):40-65.

Barnett dan Hunter. 1972. Illustrated Genera of Imperfect Fungi.

Second Edition. Virginia: Burgess Publishing Company

Birch, R.G. 2001. Xanthomonas albilineans and the antipathogenesis approach to disease control. Molecul. Plant.Pathol. 2(1):10-11.

BPPT. 2007. Melihat Industri Gula Indonesia Dari Waktu ke Waktu. Diakses dari http://lc.bppt.go.id/iptek/index 2.php?option=com_content\&d o_pdf=1\&id
Brunner, F. dan Petrini, O. 1992. Taxonomy of Some Xylaria spp. And Xylariceou Endophytes by Isozime Electrophoresis. Mycology. 96:723-733.

Cappucino, S.M dan Sherman, N. 1996. Microbiology: A Laboratory Manual. 4th Ed. Addison-Wesley Publishing Company

Dharmawan, I.W.E, Kawuri, R., dan Parwanayoni, M.S. 2009. Isolasi Streptomyces spp. Pada kawasan hutan Provinsi Bali serta uji daya hambatnya terhadap lima strain diarrheagenic Escherichia coli. Biol. 13(1):1-6.

Demain, A.L., 1998. Induction of Microbial Secondary Metabolism. Review Article. Int Microbiol 1:259-264.

Hyun, I.H., Heo, N.Y., and Lee, Y.H., 2004. Illustrated Manual on Identification of Seed Born Fungi. National Plant Quarantine Service.Anyang Korea.

Kauffman, C.A. dan Carver, P.L. 1997.Antifungal agents in the 1990s. Current status and future developments (Review). Drugs. 53:539-549. 
Kurtz, M.B. 1997. New antifungal drugs targets: A vision for the future. ASM News. 64:31-39.

Malian, A.H., Ariani, M., Indraningsih, K.S., Zakaria, A.K., Askin, A. dan Hestina, A. 2004. Revitalisasi Sistem dan Usaha Agribisnis Gula; Laporan Akhir. Puslitbang Sosial Ekonomi Pertanian, Bogor.

Mardianto, S., Simatupang, P., Hadi, P.U., Malian, H., dan Susmiadi, A. 2005. Peta jalan (road map) dan kebijakan pengembangan gula nasional. Forum penelitian Agro Ekonomi 23 (1): 19-37.

Maria, G.L., Sridhar, K.R, dan Raviraja, N.S. 2005. Antimicrobial and enzyme activity of mangrove endophytic fungi of southwest coast of India. J. Agricult Technol. 1:67-80.

Nofiani, R., Nurbetty, S., dan Sapar, A. 2009. Aktivitas antimikroba ekstrak metanol bakteri berasosiasi dengan spons dari Pulau Lemukutan Kalimantan Barat. J. Ilmu dan Teknologi Kelautan Tropis. 1(2):33-41.

Pavithra, N., Sathish, L., dan Ananda, K., 2012. Antimicrobial and Enzyme Activity of Endophytic Fungi Isolated from Tulsi. J. Pharmaceutical Biomedical Sci. 6(12):1-6.

Prabavathy, D. and Nachiyar, C.V. 2012. Study on the antimicrobial activity of Aspergillus sp isolated from Justicia adathoda. J. Sci. Technol. 5(9):3317-3320.

Pusat Penelitian dan Pengembangan Gula Indonesia (P3GI). 2007. Studi Konsolidasi Pergulaan Nasional. Kerjasama Ditjen BPP Deptan dengan P3GI, Jakarta.
Rante, H., Burhanuddin T., dan Soendaria, I. 2013. Isolasi Fungi Endofit Penghasil Senyawa antimikroba dari Daun Cabai Katokkon (Capsicum annuum L var. chinensis) dan Profil KLT Bioautografi. Majalah Farmasi dan Farmakologi. 17(2):39-49

Rodrigues KF. 1994. The foliar fungal endophtes of the Amozonian palm. Euterpe oleracea. Mycologia 86:376385.

Schaad, N.W., Jones, J.B. and Chun, W. 2000. Laboratory Guide for Identification of Plant Pathogenic Bacteria. Third edition. American Phytopathological Society, APS Press, St. Paul.

Sinaga, M.H. 2009. Pengaruh Bio VaMikoriza Dan Pemberian Arang Terhadap Jamur Fusarium oxysporum Pada Tanaman Cabai (Capsicum annuum) Di Lapangan. Universitas Sumatera Utara, Medan.

Singh, I.P., Bharate, S.B. 2005. AntiHIV Natural Products. J. Current Scien. 89:269-290.

Strobel, G., Daisy, B., Castillo, U. and Harper, H. 2004. Natural products from endophytic microorganisms. Nat.Product. 6(7):257-268.

Sunarmi, N. 2010. Isolasi dan Identifikasi Jamur Endofit Dari Akar Tanaman Kentang Sebagai Anti Jamur (Fusarium sp, Phytoptora infestans) dan Anti Bakteri (Ralstonia solanacaerum). Fakultas Sains Dan Teknologi. Universitas Islam Negeri Malang. Malang.

Suwanto, A., Friska, B. dan Sudirman, I. 1996. Karakterisasi 
Pseudomonas fluorescens B29 dan B39; Profil DNA Genom, Uji Hipersensitivitas, dan Asai

Tawiah, A.A., Stephen, Y.G., Francis, A., Vivian, E.B. and Kofi, A. 2012. Antibiotic producing microorganisms from River Wiwi, Lake Bosomtwe and the Gulf of Guinea at Doakor Sea Beach, Ghana. BMC Microbiol. 12(234):2-8.

Widodo dan Suheri. 2000. Suppression of clubroot
Senyawa Bioaktif. Hayati. 3(1):15-20p.

disease of cabbage by soil solarisation. Bul.HPT. 8(2):4955.

Yulianti, T. 2012. Menggali Potensi Endofit untuk Meningkatkan Kesehatan Tanaman Tebu Mendukung Peningkatan Produksi Gula. Perspektif. 11(2):111-112 